\title{
DISTRIBUTION AND COMMUNITY STRUCTURE OF MANGROVE IN DONROTU, GURATU AND MANOMADEHE ISLANDS, WEST HALMAHERA DISTRICT, NORTH MALUKU
}

\author{
DISTRIBUSI DAN STRUKTUR KOMUNITAS MANGROVE DI PULAU \\ DONROTU, GURATU DAN MANOMADEHE KABUPATEN \\ HALMAHERA BARAT, MALUKU UTARA
}

\author{
Rugaya H. Serosero ${ }^{1 *}$, Salim Abubakar ${ }^{1}$, \& Said Hasan ${ }^{2}$ \\ ${ }^{1}$ Study Program of Aquatic Resources Management, FPK-UNKHAIR, \\ Ternate, 97551, Indonesia \\ ${ }^{2}$ Study Program Biology, FKIP-UNKHAIR, Ternate, 97551, Indonesia \\ *E-mail: rugayaserosero@yahoo.co.id
}

\begin{abstract}
Mangrove is an ecosystem that is a habitat for various both aquatic and terrestrial biota. This research aims at revealing the distribution and community structure of mangrove in Donrotu, Guratu and Manomadehe Islands, West Halmahera Regency, North Maluku. This work was conducted from April to June 2019. Data collection using the spot check method, while the analysis of mangrove distribution was carried out qualitatively. Community structures quantitatively include type density (Di), relative density types (RDi), frequency types (Fi), relative frequency types (Rfi), closing types (Ci), closure of relatively types $(\mathrm{RCi})$, and Important value $\left(\mathrm{VI}_{\mathrm{i}}\right)$. The results showed that Rhizophora stylosa in the three islands (Donrotu, Guratu, and Idamdehe) had the highest species density and highest density values. Closing types and closures are relatively varied. The type of $R$. stylosa also has a higher importance in all three islands. The highest mangrove density was mainly found in Donrotu Island $\left(0.96 \mathrm{ind} / \mathrm{m}^{2}\right)$, then Guratu Island $\left(0.46 \mathrm{ind} / \mathrm{m}^{2}\right)$, and Idamadehe Island $\left(0.32 \mathrm{ind} / \mathrm{m}^{2}\right)$, respectively.
\end{abstract}

Keywords: community structure, distribution, Donrotu, Guratu, Manomadehe

\section{ABSTRAK}

Mangrove merupakan ekosistem yang merupakan habitat bagi berbagai biota perairan maupun di darat. Penelitian yang dilakukan ini bertujuan untuk mengungkapkan distribusi dan struktur komunitas hutan mangrove di Pulau Donrotu, Guratu dan Manomadehe Kecamatan Jailolo Selatan, Kabupaten Halmahera Barat, Maluku Utara. Pelaksanaan penelitian pada bulan April-Juni 2019. Pengambilan data dengan menggunakan metode spot check. Analisis data distribusi mangrove dilakukan secara kualitatif, sedangkan struktur komunitas secara kuantitatif meliputi kerapatan jenis (Di), kerapatan relatif jenis (RDi), frekuensi jenis (Fi), frekuensi relatif jenis (Rfi), penutupan jenis $(C i)$, penutupan relatif jenis $(R C i)$, Nilai penting $\left(V I_{i}\right)$. Hasil penelitian menunjukkan bahwa mangrove jenis Rhizophora stylosa pada ketiga pulau (Pulau Donrotu, Guratu dan Manomadehe) memiliki nilai kerapatan jenis dan kerapatan relatif jenis yang lebih tinggi. Penutupan jenis dan penutupan relatif jenis bervariasi. Jenis $R$. stylosa juga memiliki nilai penting yang lebih tinggi di ketiga Pulau. Kerapatan mangrove tertinggi ditemukan di Pulau Donrotu $\left(0,96\right.$ ind $\left./ \mathrm{m}^{2}\right)$, kemudian Pulau Guratu $\left(0,46 \mathrm{ind} / \mathrm{m}^{2}\right)$ dan Pulau Manomadehe $\left(0,32 \mathrm{ind} / \mathrm{m}^{2}\right)$.

Kata kunci: distribusi, Donrotu, Guratu, Manomadehe, struktur komunitas

\section{INTRODUCTION}

Mangrove ecosystem is a typical forest that has a dual function for resources that make it a habitat both in the waters (fish, nonfish) and in the terrestrial (birds). The community of mangrove forests is also used by humans for various purposes such as wood, as pillars of houses, cultivated land, tourist areas, and also for transportation. 
Mangroves provide a variety of essential benefits for people in the tropics and subtropics area, namely as providers of wood, food for surrounding resources including fisheries production, regulating climate regulation, water purification, coastal protection, erosion control, as a place of recreation, aesthetic and spiritual value (Polidoro et al., 2010; Barbier et al., 2011; Donato et al., 2011; McIvor et al., 2012; Vo et al., 2012). Mangroves, with all their uniqueness, have the potential to be used as tourist attractions and function to protect coastal areas from various physical threats such as sedimentation, abrasion, and prevention of seawater intrusion.

Mangrove can grow well in the areas protected from destructive human activities and physical disturbances in coastal areas. Mangrove has a unique ability to adapt to extreme environmental conditions, such as inundated soil conditions, high salinity, and less stable soil conditions (Noor et al., 2006). Mangrove ecosystems is the unity between mangrove vegetation communities associated with fauna and micro-organisms so that they can grow and develop in areas along the coast, especially in tidal areas, lagoons, estuaries rivers that are protected by sandy mud or mud substrates in forming a sustainable environmental balance (Presidential Regulation of the Republic of Indonesia, 2012). Furthermore, the forestry minister's regulation in 2013 explained that in a mangrove forest ecosystem consists of various types of mangroves that have different functions and adaptations to environmental changes that occur. Mangrove forests are a formation of trees that grow on alluvial soil in the coastal area and around tidal estuaries that are affected by sea tides. The discovery of Avicennia spp. characterizes mangrove forests. (Apiapi), Soneratia spp. (Pedada), Rhizophora spp. (Mangrove), Bruguiera spp. (Tanjang), Lumnitzera spp. (Tarumtum), Xylocarpus spp. (Nyirih), Anisoptera, and Nypa fruticans (Nipah).
Indonesia is a country that has the most extensive mangrove ecosystem in the world, with an area of approximately 3.489.140,68 ha in the year 2015 (Ministry of Environment and Forestry, 2017). The area of mangrove has been reduced due to various activities such as logging for timber, conversion to settlements agriculture and cultivation as well. Thomas et al. (2017) based on observations using data from Japanese Earth Resources Satellite (JERS-1), Synthetic Aperture Radar (SAR) and Advanced Satellite Observing Land (ALOS) and Phased Array-type L-band SAR (PALSAR) found that there has been a reduction in mangrove area in Southeast Asia as a result of human activities, namely anthropogenic degradation (33.8\%), including conversion to cultivation and agriculture. The benefits of mangrove forests are huge for humans and other resources that live in the ecosystem, but the level of loss of mangrove forests in the world is getting higher and faster (Valiela et al., 2001; Alongi, 2002; Polidoro et al., 2010). FAO (2005) stated that the uses of mangrove areas had been carried out since 1980, especially for coastal area development activities and cultivation activities.

Mangrove ecosystem spread out throughout the North Maluku region with different areas. The area of North Maluku mangrove forest is approximately 46259.41 ha. The West Halmahera region, which is the overall research location, has mangrove forests with an area of approximately 4735.8 ha. Based on the results of digitizing and image processing using high-resolution imagery carried out by BPDASHL Ake Malamo with the Directorate of Soil and Water Conservation, Director General of PDASHL in 2017, the total area of North Maluku mangrove has shrunk to 41228.7 ha or reduced by 5030.71 ha $(10.87 \%)$. This destruction was caused by natural factors and human factors (Mahmud, 2017).

West Halmahera Regency has a high potential for mangrove forests. The condition 
of mangroves on these islands has been partially utilized for various purposes. Various problems with these ecosystems include habitat degradation and reduced function of mangrove forests as spawning areas and upbringing areas for aquatic biota. Distribution of mangrove forests in a community and its community structure in an ecosystem is essential information that is needed to reveal the condition of mangrove forests in an area. The new insight and understanding of this information can be used as a basis for efforts to manage mangrove forests in the future. This research aims to reveal the distribution and community structure of mangrove forests on Donrotu Guratu and Manomadehe Islands, West Halmahera Regency, North Maluku.

\section{RESEARCH METHODS}

\subsection{Site and Time of Research}

This research was carried out on the islands of South Jailolo District (Donrotu, Guratu, and Manomadehe Islands) West
Halmahera Regency (Figure 1) from April to June 2019.

\subsection{Data Collection}

Sampling was carried out using "spot checking" (Abubakar \& Achmad, 2013). While, the distribution of mangrove species on three islands (Manomadehe, Donrotu, and Guratu) was determined descriptively, according to Noor et al. (2006). The determination of zoning patterns is illustrated by using the Canvas program 15 . Then, the thickness of the mangrove was measured manually by using a vertically drawn roll meter, starting from the front zone to the back zone, and mapping results using.

The transects were extended perpendicular to the coastline along the mangrove vegetation. While each station drew the trajectory by three pieces, and each track was placed in five plots. On each transects, vegetation data was taken using plots measuring $10 \mathrm{~m} \times 10 \mathrm{~m}$ for the tree category, $5 \mathrm{~m} \times 5 \mathrm{~m}$ for the tillers category, and $2 \mathrm{~m} \times 2 \mathrm{~m}$ for the seedling category.

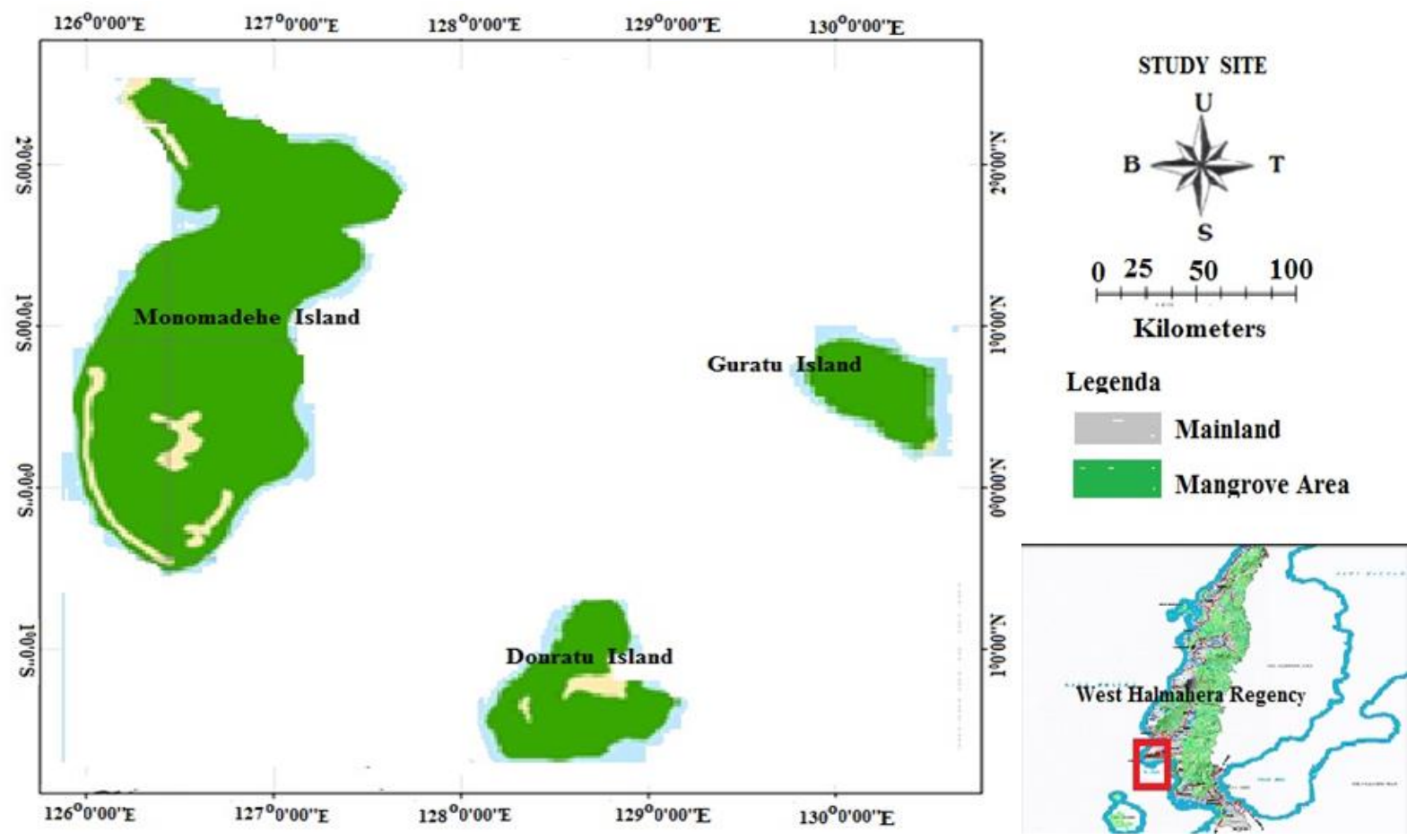

Figure 1. Study site. 
A biological sample was taken in the form of components of leaves, flowers, and fruit to identify mangrove species, and measured by a circle of stems for each mangrove tree at certain levels the identification of mangrove plants based on the guidelines of Noor et al. (2006).

\subsection{Data Analysis}

The mangrove community structure used a statistical analysis approach. The data analysis used was as follows (Bengen, 2002).

\subsubsection{Species Density}

$D_{i}=\frac{n_{i}}{A}$

$D_{i}=$ i-species density; $n_{i}=$ number of individual boxes of species-i; $A=$ total area of sampling.

\subsubsection{Species Relative Density}

$R D_{i}=\frac{n_{i}}{\sum n} \times 100$

$\mathrm{RDi}=$ species relative density; $\mathrm{ni}=$ total number of individuals of species-i; $\sum \mathrm{n}=$ total number of individuals of all species.

\subsubsection{Species Frequency}

$F_{i}=\frac{p_{i}}{\sum p}$

$F_{i}=\mathrm{i}$-species frequency; $p_{i}=$ number of sample plots where species-i was found; $\Sigma p$ $=$ total number of sample plots observed.

\subsubsection{Species Relative Frequency}

$R F_{i}=\frac{F_{i}}{\sum F} \times 100$

$R F_{i}=$ relative frequency of species; $F_{i}=$ frequency of species i; $\sum F=$ number of frequencies for all species.

\subsubsection{Closure of Species}

$C_{i}=\frac{\sum B A}{A}$

$\mathrm{BA}=\pi \mathrm{DBH} 2 / 4$ (in $\mathrm{cm} 2$ ); $\Pi=\mathrm{A}$ constant (3.1416); $\mathrm{DBH}=$ tree diameter of type $\mathrm{i} ; \mathrm{A}=$ Total area of sampling (total sample plot area).

\subsubsection{Relative Closure of Species}

$R C_{i}=\frac{C_{i}}{\sum C} \times 100$

$R C_{i}=$ closing relative type; $C_{i}=$ area of species cover; $\sum C=$ total area of closure for all species.

\subsubsection{Species Important Value}

$I V_{i}=R D_{i}+R F_{i}+R C_{i}$

Important values of a species range from 0$300 \%$. This important value provides an overview of the influence or role of a type of mangrove in the mangrove community.

\section{RESULTS AND DISCUSSION}

\subsection{Result}

\subsubsection{Species Distribution}

The species of mangroves found during the observations were grouped into six families and ten species. The composition of the mangrove species was distributed to the three islands, namely Donrotu, Guratu, and Manomadehe, with different percentages (Figure 2 and Table 1). Donrotu Island has a higher distribution of 10 species of mangrove or $45 \%$, then Guratu Island has seven species or $32 \%$, and the lowest distribution was on Manomadehe Island with five species or $23 \%$ (Figure 2). 


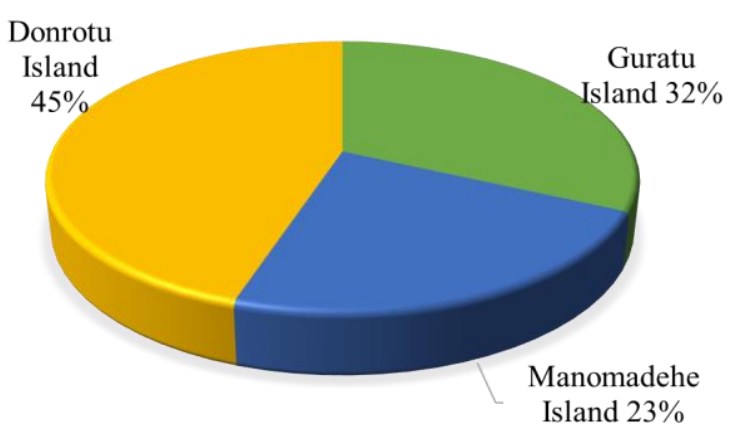

Figure 2. Percentage of mangrove distribution.

The Rhizophoraceae family dominates the mangrove species on all three islands, while the other families consist of only one species. The table also shows that the highest distribution of mangrove species was found on Donrotu Island of 10 species and the lowest on Manomadehe Island of 5 species (Table 1). Distribution of mangroves in all three locations forms a different zoning pattern from the front (front zoning) to the back (back zone or outermost zoning) (Figures 3, 4, and 5).

The zoning type of mangrove ecosystem on Manomadehe Island in the front zone is dominated by $R$. stylosa at a distance of $0-10 \mathrm{~m}$ with the type associated with $R$. apiculata. At a distance of $10-20 \mathrm{~m}$ dominated by $S$. alba with the type associated was $C$. tagal. In the middle zone with a distance of $20-30 \mathrm{~m}$ dominated by $R$. apiculata with species associated with $B$. gymnorrhiza and $R$. apiculata, respectively. At a distance of $30-40 \mathrm{~m}$ was dominated by $S$. $a l b a$, with the associated species were $C$. tagal and B. gymnorrhiza. In the back zone with a distance of 40-50m dominated by $S$. $a l b a$, the species associated were $R$. stylosa and B. gymnorrhiza.

The zonation type of mangrove ecosystem on Donrotu Island in the front zone was dominated by $R$. stylosa at a distance of 0-10m with the species associated were $R$. apiculata and B. gymnorrhiza. At a distance of $10-20 \mathrm{~m}$ was dominated by $R$. mucronata with species associated were $B$. gymnorrhiza and $S$. alba. In the middle zone with a distance of $20-30 \mathrm{~m}$ dominated by $C$. tagal with the type associated was $R$. apiculata. At a distance of $30-40 \mathrm{~m}$ was dominated by $R$. stylosa with the species associated were $C$. tagal and S. alba. In the rear zone with a distance of $40-50 \mathrm{~m}$, dominated by $B$. gymnorrhiza with the species associated were $A$. alba, H. littoralis, and $X$. granatum.

Table 1. Composition and distribution of mangrove in Manomadehe, Donrotu, and Guratu Island.

\begin{tabular}{|c|c|c|c|c|c|}
\hline \multirow[b]{2}{*}{ No. } & \multirow[b]{2}{*}{ Family } & \multirow[b]{2}{*}{ Species } & \multicolumn{3}{|c|}{ Distribution } \\
\hline & & & $\begin{array}{l}\text { Manomadehe } \\
\text { island }\end{array}$ & $\begin{array}{l}\text { Donrotu } \\
\text { island }\end{array}$ & $\begin{array}{l}\text { Guratu } \\
\text { island }\end{array}$ \\
\hline \multirow[t]{5}{*}{1} & Rhizophoraceae & Rhizophora apiculata & + & + & + \\
\hline & & Rhizophora mucronata & - & + & + \\
\hline & & Rhizophora stylosa & + & + & + \\
\hline & & Bruguiera gymnorrhiza & + & + & + \\
\hline & & Ceriops tagal & + & + & + \\
\hline 2 & Sonneratiaceae & Sonneratia alba & + & + & + \\
\hline 3 & Meliaceae & Xylocarpus granatum & - & + & + \\
\hline 4 & Avicenniaceae & Avicennia alba & - & + & - \\
\hline 5 & Sterculiaceae & Heritiera littoralis & - & + & - \\
\hline 6 & Combretaceae & Lumnitzera littorea & - & + & - \\
\hline
\end{tabular}

Description : $+:$ There is - : There is no 


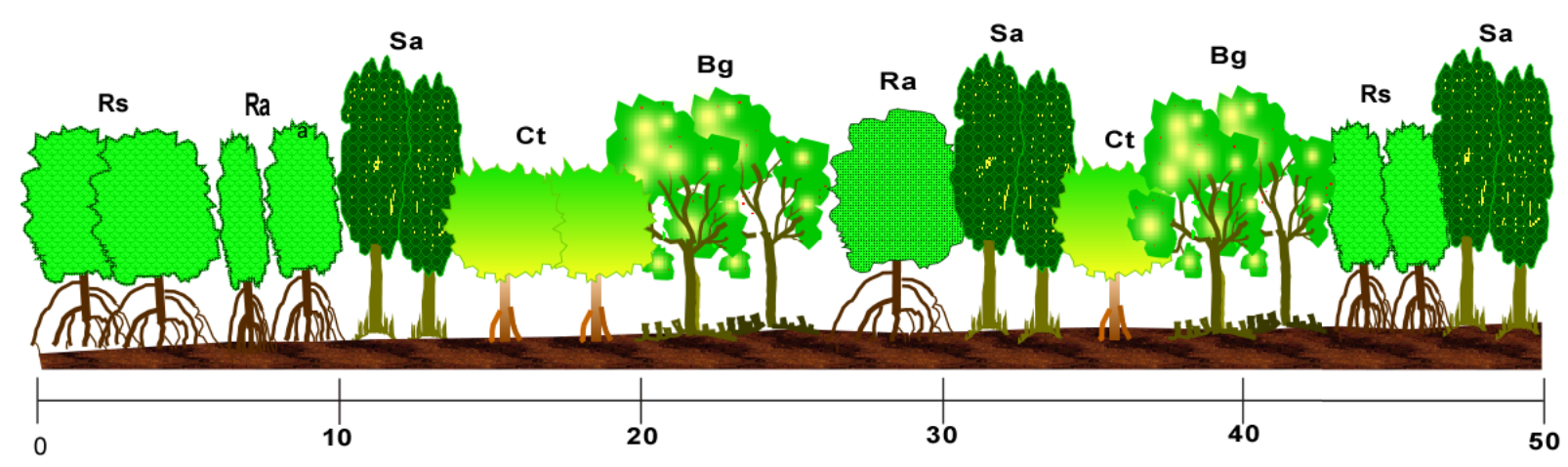

Figure 3. Type of zoning of the mangrove ecosystem in Manomadehe Island. Discription: Rs: R. stylosa, Ra: R. apiculata, Sa: S. alba, Ct: C. tagal, Bg: B. gymnorrhiza.

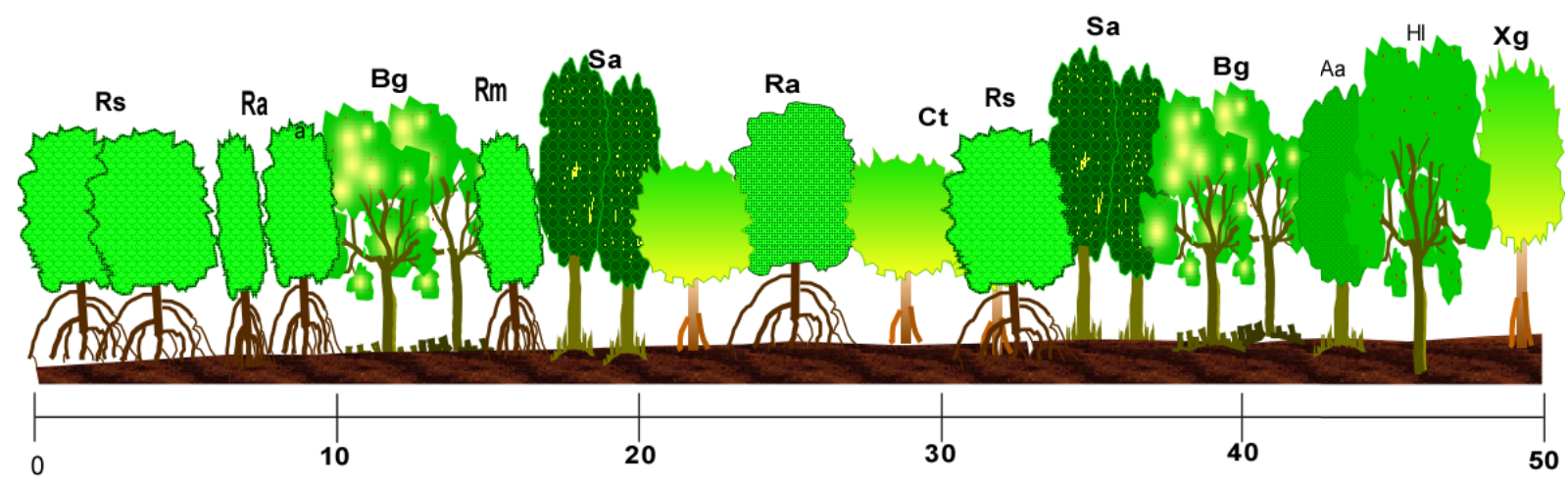

Figure 4. Type of zoning of the mangrove ecosystem in Donrotu Island. Description: Rs: $R$. stylosa, Ra: R. apiculata, Rm: R. mucronata, Bg: B. gymnorrhiza, Sa: S. alba, Ct: Ceriops tagal, Aa: A. alba, $\mathrm{Hl}:$ H. littoralis, Xg : X. granatum.

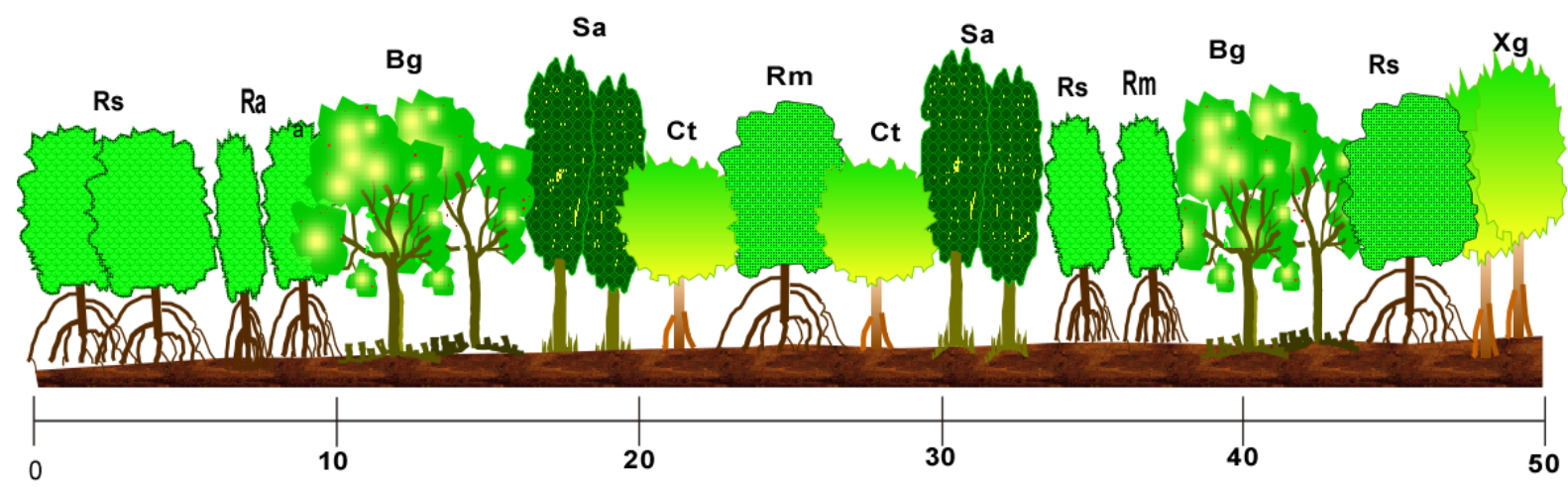

Figure 5. Type of zoning of the mangrove ecosystem in Guratu Island. Description: Rs: $R$. stylosa, Ra: $R$. apiculata, Bg: B. gymnorrhiza, Sa: S. alba, Ct: C. tagal, Rm: $R$. mucronata, Xg: X. granatum.

The zonation type of mangrove ecosystem on Guratu Island in the front zone was dominated by $R$. stylosa at a distance of $0-10 \mathrm{~m}$ with the species associated were $R$. apiculata. At a distance of $10-20 \mathrm{~m}$ was dominated by $B$. gymnorrizha with species associated were $S$. alba. In the middle zone with a distance of $20-30 \mathrm{~m}$ dominated by $C$. tagal with the type associated was $R$. mucronata. At a distance of $30-40 \mathrm{~m}$ was 
dominated by $R$. stylosa with the species associated were $S$. alba and $R$. mucroanat. In the rear zone with a distance of $40-50 \mathrm{~m}$, dominated by $R$. stylosa with the species associated were B. gymnorrhiza and $X$. granatum.

The results of measurements of environmental quality, which include temperature, salinity, and $\mathrm{pH}$ of mangrove soils on three islands (Table 2), indicate that these locations are suitable habitats for mangrove growth.

\subsubsection{Mangrove Ecosystem Community Structure}

The community structure of the mangrove ecosystem in Manomadehe, Donrotu, and Guratu Island was presented vertically in Tables 3,4 and 5 . The community structure of the mangrove ecosystem illustrates the condition of mangrove in the three islands quantitatively.

$R$. stylosa dominated the mangrove forest community in Manomadehe Island with the highest density, species density, species frequency, and the highest frequency relative compared to other species. The species with the highest closure was found on Sonneratia alba. From the five species found, $R$. stylosa had the highest of the important values, whereas $R$. apiculata was the lowest one. The mangrove community structure in Donrotu Island is shown in Table 4 and Guratu Island in Table 5.

The highest density, relative density, species frequency, and relative frequency of the highest species were found on R. stylosa, while the highest type closure and the highest type of closure were found on $S$. alba. The table also shows that $R$. stylosa has the highest important value, whereas $H$. littoralis was the lowest one.

$R$. stylosa has the species density, relative density, species frequency, and the highest relative species frequency. The species frequency was relatively the lowest on $R$. mucronata, $C$. tagal, and $X$. granatum species $(0.27$ or $8.33 \%)$. The closing of the type and relative closure of the highest types were S. alba $(22.43$ or $44.70 \%)$ and the lowest $C$. tagal $(0.49$ or $0.98 \%)$. While the highest important values were $R$. stylosa (74.50), and the lowest one was $C$. tagal (13.70) (Table 5).

Horizontally mangrove vegetation community structures in Manomadehe Island, Donrotu Island, and Guratu Island district are presented in Tables 6, 7 and 8 .

The species density and the species relative density were $R$. stylosa $\left(0.06 \mathrm{ind} / \mathrm{m}^{2}\right.$ or $41.10 \%$ ), and the lowest one was $C$. tagal $\left(0.01 \mathrm{ind} / \mathrm{m}^{2}\right.$ or $5.05 \%$. Species frequency and the highest species relative frequency were $R$. stylosa $(0.67$ or $33.33 \%)$, and the lowest one was S. alba $(0.20$ or $10.00 \%)$. Species closure and the highest species relative closure were $S$. alba (18.16 or $40.39 \%$ ), and the lowest one was C. tagal (2.10 or $4.67 \%)$. Meanwhile, the highest important value was $R$. stylosa (118.62), and the lowest one was $C$. tagal (23.05) (Table $6)$.

The species density and relative density were $R$. stylosa $\left(0.16 \mathrm{ind} / \mathrm{m}^{2}\right.$ or $54.68 \%$ ), and the lowest one was $X$. granatum and A. alba $\left(0.003 \mathrm{ind} / \mathrm{m}^{2}\right.$ or $0.45 \%$. Species frequency and the highest species relative frequency were $L$. littorea ( 0.73 or $20.37 \%$ ), and the lowest one was $H$. littoralis $(0.07$ or $1.85 \%)$. The highest closure species and the closure species were S. alba (23.14 or $29.14 \%$ ), and the lowest one was $C$. tagal $(0.10$ or $0.13 \%)$. Meanwhile, the highest important value was $R$. stylosa (84.78), and the lowest one was $A$. alba (8.08) (Table 7).

The highest species densities and the species relative densities $\mathrm{t}$ were $R$. stylosa $\left(0.20 \mathrm{ind} / \mathrm{m}^{2}\right.$ or $\left.58.20 \%\right)$, and the lowest one was $S$. alba $\left(0.004 \mathrm{ind} / \mathrm{m}^{2}\right.$ or $1.17 \%$. The highest species frequency and species relative frequency were $R$. stylosa (1.00 or $26.32 \%$ ), and the lowest one was $C$. tagal and $X$. granatum $(0.40$ or $10.53 \%)$. The species closure and the highest species closure were $S$. alba $(25.65$ or $32.60 \%)$, and 
the lowest one was $C$. tagal $(0.31$ or $0.39 \%)$. were $R$. stylosa (97.38), and the lowest one Meanwhile, the highest important values was $C$. tagal (15.41) (Table 8).

Table 2. Parameters of the mangrove environment and several other research results.

\begin{tabular}{|c|c|c|c|c|c|}
\hline \multirow[b]{2}{*}{ Source } & \multicolumn{4}{|c|}{ Parameter Range } & \multirow[b]{2}{*}{$\begin{array}{l}\text { Substrat } \\
\text { type }\end{array}$} \\
\hline & $\begin{array}{l}\text { Suhu } \\
\left({ }^{\circ} \mathrm{C}\right)\end{array}$ & $\mathrm{pH}$ & $\begin{array}{l}\text { Salinitas } \\
\text { (ppm) }\end{array}$ & Locations & \\
\hline $\begin{array}{l}\text { Juliandri et al. } \\
(2018)\end{array}$ & $29-30.33$ & - & $27-29$ & Karangsong Indramayu & Sand, loam \\
\hline Zamdial (2016) & $28.6-30.7$ & $6.80-6.96$ & $0.1-2.0$ & $\begin{array}{l}\text { Pasar villege, } \\
\text { Mukomuko distric }\end{array}$ & - \\
\hline $\begin{array}{l}\text { Tefarani et al. } \\
\text { (2019) }\end{array}$ & $26.5-28$ & $6-7$ & $16-20$ & $\begin{array}{l}\text { Kelurahan Tugu, } \\
\text { Semarang city }\end{array}$ & Sand, loam \\
\hline $\begin{array}{l}\text { Mughofar et al. } \\
\text { (2018) }\end{array}$ & $30-32$ & $6.4-6.9$ & $4-6$ & Karanggandu, Trenggalek & Clay \\
\hline \multirow[t]{3}{*}{ This research) } & $24-28$ & $6.2-6.7$ & $27-30$ & Manomadehe island & Clay \\
\hline & $29-32$ & $6.3-6.7$ & $30-32$ & Donrotu island & Loamy sand \\
\hline & $29-31$ & $6.0-6.7$ & $30-31$ & Guratu island & Sandy Loam \\
\hline
\end{tabular}

Table 3. Community structure analysis of the mangrove ecosystem in Manomadehe Island.

\begin{tabular}{llccccccc}
\hline \multirow{2}{*}{ No. } & \multirow{2}{*}{ Species } & \multicolumn{6}{c}{ Variable of mangrove ecosystem community structure } \\
\cline { 3 - 9 } & $\begin{array}{c}\mathrm{Di} \\
\left(\mathrm{ind} / \mathrm{m}^{2}\right)\end{array}$ & $\begin{array}{c}\mathrm{RDi} \\
(\%)\end{array}$ & $\mathrm{Fi}$ & $\begin{array}{c}\mathrm{RFi} \\
(\%)\end{array}$ & $\mathrm{Ci}$ & $\begin{array}{c}\text { Rci } \\
(\%)\end{array}$ & $\begin{array}{c}\mathrm{VI}_{\mathrm{i}} \\
(\%)\end{array}$ \\
\hline 1 & R. apiculata & 0.04 & 11.25 & 0.40 & 12.00 & 6.34 & 11.78 & 35.04 \\
2 & R. stylosa & 0.13 & 39.17 & 0.93 & 28.00 & 17.45 & 32.42 & 99.62 \\
3 & B. gymnorrhiza & 0.10 & 30.83 & 0.47 & 14.00 & 5.23 & 9.72 & 54.56 \\
4 & C. tagal & 0.04 & 13.33 & 0.80 & 24.00 & 2.53 & 4.70 & 42.06 \\
5 & S. alba & 0.02 & 5.42 & 0.73 & 22.00 & 22.27 & 41.38 & 68.82 \\
\hline \multicolumn{2}{c}{ Total } & 0.32 & 100.00 & 3.33 & 100.00 & 53.82 & 100.00 & 300.00 \\
\hline
\end{tabular}

Table 4. Community structure analysis of the mangrove ecosystem in Donrotu Island.

\begin{tabular}{|c|c|c|c|c|c|c|c|c|}
\hline \multirow[b]{2}{*}{ No. } & \multirow[b]{2}{*}{ Species } & \multicolumn{7}{|c|}{ Variable of mangrove ecosystem community structure } \\
\hline & & $\begin{array}{c}\mathrm{Di} \\
\left(\mathrm{ind} / \mathrm{m}^{2}\right)\end{array}$ & $\begin{array}{l}\text { RDi } \\
(\%)\end{array}$ & $\mathrm{Fi}$ & $\begin{array}{l}\mathrm{RFi} \\
(\%)\end{array}$ & $\mathrm{Ci}$ & $\begin{array}{l}\mathrm{RCi} \\
(\%)\end{array}$ & $\begin{array}{l}\mathrm{VI}_{\mathrm{i}} \\
(\%)\end{array}$ \\
\hline 1 & R. apiculata & 0.07 & 7.74 & 0.60 & 13.64 & 12.87 & 11.40 & 32.78 \\
\hline 2 & R. mucronata & 0.03 & 2.93 & 0.20 & 4.55 & 6.87 & 6.09 & 13.56 \\
\hline 3 & R. stylosa & 0.34 & 35.36 & 0.73 & 16.67 & 17.05 & 15.11 & 67.13 \\
\hline 4 & B. gymnorrhiza & 0.25 & 26.29 & 0.40 & 9.09 & 13.34 & 11.82 & 47.20 \\
\hline 5 & C. tagal & 0.09 & 9.83 & 0.47 & 10.61 & 1.43 & 1.27 & 21.71 \\
\hline 6 & S. alba & 0.02 & 1.74 & 0.33 & 7.58 & 41.46 & 36.74 & 46.06 \\
\hline 7 & $X$. granatum & 0.02 & 1.81 & 0.47 & 10.61 & 6.65 & 5.89 & 18.31 \\
\hline 8 & A. alba & 0.02 & 2.51 & 0.40 & 9.09 & 6.92 & 6.13 & 17.73 \\
\hline 9 & H. littoralis & 0.02 & 1.74 & 0.27 & 6.06 & 2.42 & 2.14 & 9.95 \\
\hline 10 & L. littorea & 0.10 & 10.04 & 0.53 & 12.12 & 3.84 & 3.40 & 25.57 \\
\hline & Total & 0.96 & 100.00 & 4.40 & 100.00 & 112.85 & 100.00 & 300.00 \\
\hline
\end{tabular}


Table 5. Community structure analysis of the mangrove ecosystem on Guratu Island.

\begin{tabular}{|c|c|c|c|c|c|c|c|c|}
\hline \multirow[b]{2}{*}{ No. } & \multirow[b]{2}{*}{ Species } & \multicolumn{7}{|c|}{ Variable of mangrove ecosystem community structure } \\
\hline & & $\begin{array}{c}\mathrm{Di} \\
\left(\mathrm{ind} / \mathrm{m}^{2}\right)\end{array}$ & $\begin{array}{l}\text { RDi } \\
(\%)\end{array}$ & $\mathrm{Fi}$ & $\begin{array}{l}\mathrm{RFi} \\
(\%)\end{array}$ & $\mathrm{Ci}$ & $\begin{array}{l}\mathrm{RCi} \\
(\%)\end{array}$ & $\begin{array}{l}\mathrm{VI}_{\mathrm{i}} \\
(\%)\end{array}$ \\
\hline 1 & R. apiculata & 0.04 & 8.19 & 0.53 & 16.67 & 5.53 & 11.02 & 35.87 \\
\hline 2 & R. mucronata & 0.09 & 19.74 & 0.27 & 8.33 & 11.03 & 21.98 & 50.05 \\
\hline 3 & R. stylosa & 0.18 & 39.62 & 0.80 & 25.00 & 4.96 & 9.88 & 74.50 \\
\hline 4 & B. gymnorrhiza & 0.09 & 20.47 & 0.40 & 12.50 & 2.74 & 5.46 & 38.43 \\
\hline 5 & C. tagal & 0.02 & 4.39 & 0.27 & 8.33 & 0.49 & 0.98 & 13.70 \\
\hline 6 & S. alba & 0.02 & 4.82 & 0.67 & 20.83 & 22.43 & 44.70 & 70.36 \\
\hline 7 & $X$. granatum & 0.01 & 2.78 & 0.27 & 8.33 & 3.00 & 5.98 & 17.09 \\
\hline & Total & 0.46 & 100.00 & 3.20 & 100.00 & 50.18 & 100.00 & 300.00 \\
\hline
\end{tabular}

Table 6. Community structure analysis of mangrove forests in Manomadehe Island.

\begin{tabular}{|c|c|c|c|c|c|c|c|c|}
\hline \multirow[b]{2}{*}{ No. } & \multirow[b]{2}{*}{ Species } & \multicolumn{7}{|c|}{ Variable of mangrove ecosystem community structure } \\
\hline & & $\begin{array}{c}\mathrm{Di} \\
\left(\mathrm{ind} / \mathrm{m}^{2}\right)\end{array}$ & $\begin{array}{l}\mathrm{RDi} \\
(\%)\end{array}$ & $\mathrm{Fi}$ & $\begin{array}{l}\mathrm{RFi} \\
(\%)\end{array}$ & $\mathrm{Ci}$ & $\begin{array}{c}\mathrm{RCi} \\
(\%)\end{array}$ & $\begin{array}{l}\mathrm{IVi}_{\mathrm{i}} \\
(\%)\end{array}$ \\
\hline 1 & R. apiculata & 0.03 & 23.23 & 0.47 & 23.33 & 5.15 & 11.45 & 58.02 \\
\hline 2 & R. stylosa & 0.06 & 48.99 & 0.67 & 33.33 & 16.32 & 36.30 & 118.62 \\
\hline 3 & B. gymnorrhiza & 0.02 & 15.15 & 0.40 & 20.00 & 3.23 & 7.18 & 42.34 \\
\hline 4 & C. tagal & 0.01 & 5.05 & 0.27 & 13.33 & 2.10 & 4.67 & 23.05 \\
\hline 5 & S. alba & 0.01 & 7.58 & 0.20 & 10.00 & 18.16 & 40.39 & 57.97 \\
\hline & Total & 0.13 & 100.00 & 2.00 & 100.00 & 44.96 & 100.00 & 300.00 \\
\hline
\end{tabular}

Table 7. Community structure analysis of mangrove ecosystem in Donrotu Island.

\begin{tabular}{clccccccc}
\hline \multirow{2}{*}{ No. } & \multirow{2}{*}{ Species } & \multicolumn{6}{c}{ Variable of mangrove ecosystem community structure } \\
\cline { 3 - 9 } & & $\mathrm{Di}\left(\mathrm{ind} / \mathrm{m}^{2}\right)$ & $\mathrm{RDi}(\%)$ & $\mathrm{Fi}$ & $\mathrm{RFi}(\%)$ & $\mathrm{Ci}$ & $\mathrm{RCi}(\%)$ & $\mathrm{IV}_{\mathrm{i}}$ \\
\hline 1 & R. apiculata & 0.05 & 6.96 & 0.47 & 12.96 & 8.13 & 10.24 & 30.16 \\
2 & R. mucronata & 0.02 & 2.14 & 0.20 & 5.56 & 4.51 & 5.68 & 13.38 \\
3 & R. stylosa & 0.41 & 54.68 & 0.60 & 16.67 & 10.67 & 13.43 & 84.78 \\
4 & B. gymnorrhiza & 0.16 & 21.50 & 0.40 & 11.11 & 8.56 & 10.78 & 43.39 \\
5 & C. tagal & 0.04 & 5.98 & 0.53 & 14.81 & 0.10 & 0.13 & 20.92 \\
6 & S. alba & 0.01 & 1.34 & 0.27 & 7.41 & 23.14 & 29.14 & 37.88 \\
7 & X. granatum & 0.003 & 0.45 & 0.20 & 5.56 & 10.62 & 13.37 & 19.37 \\
8 & A. alba & 0.003 & 0.45 & 0.13 & 3.70 & 3.12 & 3.93 & 8.08 \\
9 & H. littoralis & 0.004 & 0.54 & 0.07 & 1.85 & 8.23 & 10.36 & 12.75 \\
10 & L. littorea & 0.04 & 5.98 & 0.73 & 20.37 & 2.34 & 2.95 & 29.29 \\
\hline \multicolumn{2}{r}{ Total } & 0.75 & 100.00 & 3.60 & 100.00 & 79.42 & 100.00 & 300.00 \\
\hline
\end{tabular}

Table 8. Community structure analysis of the mangrove ecosystem in Guratu Island.

\begin{tabular}{clccccccc}
\hline \multirow{2}{*}{ No. } & \multirow{2}{*}{ Species } & \multicolumn{7}{c}{ Variable of mangrove forest community structure } \\
\cline { 3 - 9 } & & $\mathrm{Di}\left(\mathrm{ind} / \mathrm{m}^{2}\right)$ & $\mathrm{RDi}(\%)$ & $\mathrm{Fi}$ & $\mathrm{RFi}(\%)$ & $\mathrm{Ci}$ & $\mathrm{RCi}(\%)$ & $\mathrm{IV}_{\mathrm{i}}$ \\
\hline 1 & R. apiculata & 0.05 & 14.84 & 0.67 & 17.54 & 6.45 & 8.20 & 40.58 \\
2 & R. mucronata & 0.01 & 4.10 & 0.33 & 8.77 & 13.04 & 16.57 & 29.44 \\
3 & R. stylosa & 0.20 & 58.20 & 1.00 & 26.32 & 10.12 & 12.86 & 97.38 \\
4 & B. gymnorrhiza & 0.05 & 15.23 & 0.53 & 14.04 & 18.67 & 23.73 & 53.00 \\
\hline
\end{tabular}




\begin{tabular}{|c|c|c|c|c|c|c|c|c|}
\hline \multirow{2}{*}{ No. } & \multirow{2}{*}{ Species } & \multicolumn{7}{|c|}{ Variable of mangrove forest community structure } \\
\hline & & Di (ind $\left./ \mathrm{m}^{2}\right)$ & RDi (\%) & $\mathrm{Fi}$ & RFi (\%) & $\mathrm{Ci}$ & $\mathrm{RCi}(\%)$ & $\mathrm{IV}_{\mathrm{i}}$ \\
\hline 5 & C. tagal & 0.02 & 4.49 & 0.40 & 10.53 & 0.31 & 0.39 & 15.41 \\
\hline 6 & S. alba & 0.004 & 1.17 & 0.47 & 12.28 & 25.65 & 32.60 & 46.05 \\
\hline 7 & $X$. granatum & 0.01 & 1.95 & 0.40 & 10.53 & 4.45 & 5.66 & 18.13 \\
\hline & Total & 0.34 & 100.00 & 3.80 & 100.00 & 78.69 & 100.00 & 300.00 \\
\hline
\end{tabular}

\subsection{Discussion}

\subsubsection{Mangrove Distribution}

The species of $R$. apiculata, $R$. stylosa, B. gymnorrhiza, C. tagal, and S. alba species were found in Manomadehe Island, Donrotu, and Guratu based on vertical and horizontal distribution. This condition shows that these species can survive and adapt to various pressures due to both environmental changes and exploitation rates. $X$. granatum and $R$. mucronata were only found in Donrotu and Guratu islands. While $H$. littoralis was only found in Donrotu Island. The distribution ability was an indicator of the discovery of a species in the community. Usman et al. (2013) stated that Rhizophora sp was one of the mangrove species that are tolerant to environmental conditions (substrate, tides, salinity, and nutrient supply) and can spread widely and can grow upright in the various places.

The mangrove community can generally be found in coastal areas that grow and spread in the bay area or areas protected from the physical influence of waves permanently. Jusoff (2013) stated that mangroves could grow in intertidal areas and river estuaries and become a habitat for plants and marine and terrestrial animals. Alongi (2009) also stated that mangrove forests are distributed in tropical and subtropical regions in the tidal areas between sea and land around $30^{\circ} \mathrm{LU}$ and $30^{\circ} \mathrm{LS}$.

The distribution of mangroves on Donrotu Island and Guratu Island has a higher composition of mangrove species caused by this island far from residential areas. This condition caused the activities to exploit mangrove wood as firewood and house support poles to be more focused on the closer islands, namely Manomadehe
Island. The area of mangrove forest on Manomadehe Island has been partially converted into sea transportation lanes, and the amount of residential waste around the mangrove area has resulted in reduced diversity of mangroves. Siringoringo et al. (2017); Iswahyudi et al. (2019) suggested that anthropogenic influences in the form of land clearing for aquaculture and settlements affect the number of mangrove species in an area. Giri et al. (2015) found that anthropogenic activities greatly affected the extent and cover of mangroves in South Asia. Specific factors that are dominantly carried out are the conversion of mangrove land into agricultural land, shrimp farming, settlements, over-harvesting, pollution, reduced freshwater, flooding, coastal erosion, the influence of tropical cyclones and tsunamis. The tsunami that occurred in the Indian Ocean in December 2004 and other natural disasters caused mangroves to be noticed because it could make it a 'bio shield.' The existence of mangrove forests can hinder the brunt of the tsunami and protect coastal communities in Indonesia, Thailand, India, and Sri Lanka (Danielsen et al., 2005; Kathiresan \& Rajendran, 2005).

The zoning pattern formed in the three islands (Manomadehe, Donrotu, and Guratu) shows that $R$. stylosa was always in the front zone. This condition shows that Rhizophoracea can adapt to the physical disturbances in waters such as high salinity, high temperatures, and waves because it has a robust rooting form. The type of substrate in the front zone is also excellent, which allows the type of Rhizophora spp. can develop well. Masithah et al. (2016) stated that the type of Rhizophora spp. was very fond of sandy clay substrates. Overall, the 
substrate conditions in the three research sites included the soft substrate category (Table 5), which was the best substrate for mangrove growth. Noor et al. (2006) stated that mangroves mainly grow on muddy soil, but various types of mangroves can grow in sandy, rocky, gravel soils, and even peat soils. Mangroves can also grow on sandy beaches, rocky, or substrate with coral fragments.

The condition of the substrate also determines the formation of mangrove zoning in an area. Masithah et al. (2016) reported that mangrove growth is influenced by the type of substrate, namely $S$. alba species will grow well on sandy mud substrates, Rhizophora grows better on mud substrates rich in organic matter. The zoning sequence formed in three islands in the South Jailolo Subdistrict was different from the zoning pattern proposed by Noor et al. (2006) that in the open mangrove zone was often overgrown by Avicennia sp. and in the middle mangrove zone generally dominated by Rhizophora sp. The adaptability of mangroves influences the difference in zoning conditions to their environmental conditions. Zoning conditions that are not optimal are caused by the influence of environmental conditions such as soil conditions, salinity, duration of flooding, tidal currents, and human activities (Wahyudi et al., 2014). Different zoning conditions between each region show differences in environmental characteristics and utilization rates. According to Noor et al. (2006), zoning formation in each region was different and cannot be applied to other regions. Each region has a formation and zoning of overlapping and associated vegetation.

The results of measurements of environmental quality, which include temperature, salinity, and $\mathrm{pH}$ of mangrove soils on three islands (Table 9), indicate that these locations are suitable habitats for mangrove growth.

\subsubsection{Community Structure}

The highest density values of mangrove vertically species were found in Donrotu Island $\left(0.96 \mathrm{ind} / \mathrm{m}^{2}\right)$ (Table 3), and the lowest one was in Manomadehe Island $\left(0.32 \mathrm{ind} / \mathrm{m}^{2}\right)$ (Table 2). The highest horizontal mangrove species density was also found in Donrotu Island $\left(0.75 \mathrm{ind} / \mathrm{m}^{2}\right.$ ) (Table 7 ) and the lowest one was in Manomadehe Island $\left(0.13 \mathrm{ind} / \mathrm{m}^{2}\right)$ (Table 6). The high density of mangroves in Donrotu Island was probably caused by the island being far from

Table 9. Parameters of the mangrove environment and several other research results.

\begin{tabular}{|c|c|c|c|c|c|}
\hline \multirow[b]{2}{*}{ Source } & \multicolumn{5}{|c|}{ Parameter range } \\
\hline & $\begin{array}{l}\text { Suhu } \\
\left({ }^{\circ} \mathrm{C}\right)\end{array}$ & $\mathrm{pH}$ & $\begin{array}{c}\text { Salinitas } \\
\text { (ppm) }\end{array}$ & Locations & Substrat type \\
\hline $\begin{array}{l}\text { Juliandri et al. } \\
\text { (2018) }\end{array}$ & $29-30.33$ & - & $27-29$ & $\begin{array}{l}\text { Karangsong } \\
\text { Indramayu }\end{array}$ & Sand, loam \\
\hline $\begin{array}{l}\text { Zamdial } \\
(2016)\end{array}$ & $28.6-30.7$ & $6.80-6.96$ & $0.1-2.0$ & $\begin{array}{l}\text { Pasar villege, } \\
\text { Mukomuko } \\
\text { distric }\end{array}$ & - \\
\hline $\begin{array}{l}\text { Tefarani et al. } \\
\text { (2019) }\end{array}$ & $26.5-28$ & $6-7$ & $16-20$ & $\begin{array}{l}\text { Kelurahan Tugu, } \\
\text { Semarang city }\end{array}$ & Sand, loam \\
\hline $\begin{array}{l}\text { Mughofar et } \\
\text { al. (2018) }\end{array}$ & $30-32$ & $6.4-6.9$ & $4-6$ & $\begin{array}{l}\text { Karanggandu, } \\
\text { Trenggalek }\end{array}$ & Clay \\
\hline This research & $\begin{array}{l}24-28 \\
29-32 \\
29-31\end{array}$ & $\begin{array}{l}6.2-6.7 \\
6.3-6.7 \\
6.0-6.7\end{array}$ & $\begin{array}{l}27-30 \\
30-32 \\
30-31\end{array}$ & $\begin{array}{l}\text { Manomadehe } \\
\text { Donrotu } \\
\text { Guratu }\end{array}$ & $\begin{array}{c}\text { Clay } \\
\text { Loamy sand } \\
\text { Sandy Loam }\end{array}$ \\
\hline
\end{tabular}


settlement and the exploitation that was bordered to firewood. The habitat on the island of Donrotu was also very suitable for mangrove life (Table 8). This condition provides an opportunity to find more species composition and a number of stands. While the low density of species was found in Manomadehe Island caused by part of its habitat being disrupted due to the use of the community both as fuelwood and land conversion as a sea transportation route so that mangroves grow less tightly. In general, the species that has the highest density in the three islands was $R$. stylosa. Species density was related to the growth and the distance of the trees, the number of individuals found in the mangrove species, and the area of the study site. The more the number of individuals found, the higher density values. Murhum et al. (2018) found that the highest density was caused by the suitable habitat, lack of exploitation and the ability of the mangroves to adapt to the environment. The activities that occur in the area of mangrove forests in the form of excessive exploitation, conversion to agricultural land, cultivation, location of tourism and urban development that can reduce the potential of mangrove forests and even cause extinction if these activities take place sustainably (Alongi, 2002; Giri et al., 2008).

The highest frequency of individual presence vertically was found in Donrotu Island (4.40) and the lowest one was in Guratu Island (3.20). Whereas horizontally, the highest percentage of frequencies was found in Guratu Island (3.80), and the lowest ones were in Manomadehe Island (2.00). The frequency values of the presence of mangrove species were influenced by the number of species found in each plot.

The more plots of mangrove species were found, the higher the frequency of the presence of mangrove species. In general, $R$. stylosa has the highest frequency of presence in all three islands because this species was evenly distributed in each plot. According to Rumalean et al. (2019), frequency in ecology is used to express the proportion between the number of samples containing certain species to the total number of samples. A highfrequency value in one type is caused by the chance of finding this type more on each research transect.

The highest type of closure vertically was found in Donrotu Island (112.84), and the lowest one was in Guratu Island (50.18). Whereas horizontally, closure of the highest species was found in Donrotu Island (79.42) and the lowest on the island (44.96). The values of type closure were closely related to the circumference of the tree trunk. In general, the highest closure of mangrove species in the three islands was $S$. alba. This condition was closely related to the tree diameters, where if the tree diameters were large, it would have a higher closing value even though the number of individuals was small while the lowest closure were $C$. tagal because this type has a small tree diameter with the fewest number of individuals. Akbar et al. (2017) stated that the closure of mangrove species illustrates the level of closure of land, which is a mangrove growing area. The highest types of cover were caused by the large size of the stem circumference with a high canopy cover.

The species of $R$. apiculata, $R$. stylosa, B. gymnorrhiza, C. tagal, and S. alba species were found in Manomadehe Island, Donrotu, and Guratu. In general, mangroves in each island have the highest importance values of $R$. stylosa, and the lowest one was $C$. tagal (Tables 3,4,5,6,7,8). The important values were an index that provides an overview of the importance of the role or influence of a mangrove vegetation in a research location. The important index value between 0-300 showed the representation of the type of mangrove that plays a role in the ecosystem, so if $\mathrm{VI}_{\mathrm{i}} 300$ means that mangroves have an important role in the coastal environment (Bengen, 2002). Important values were a quantitative parameter that can be used to express the level of dominance. The high value of the 
important index of $R$. stylosa showed that $R$. stylosa plays a relatively significant role in maintaining the sustainability of the mangrove ecosystem. The high importance values were owned by the dominant species in a community (Indrayanti, 2015). Thus, $R$. stylosa has a significant influence and role in the mangrove vegetation community in all islands. The role of a mangrove species towards the community can be seen from the results of vegetation conditions that indicate whether good growth or not.

\section{CONCLUSION}

Distribution of mangroves in the three different islands, Donrotu Island consists of 10 species of mangroves, seven species of Guratu Island, and five in Manomadehe Island. These differences were caused by the distance of the three islands to the settlements, which allows the exploitation rates for different uses in the islands. The type of $R$. stylosa has a higher density, species density, frequency, species, and importance values than other mangrove species in these three islands (Manomadehe, Donrotu, and Guratu). This condition showed that $R$. stylosa has high adaptive abilities in the three islands.

\section{ACKNOWLEDGMENT}

Our thanks go to the Kharun University Rector, Mr. Prof. Dr. Husen Alting, SH. MH. and the chairman of LPPM, Mrs. Nurhasanah Yusuf, S. Si, M. Si, for the financial assistance provided through college grant activities so that this research activity could be carried out. Our thanks also go to field staff who have helped during our fieldwork.

\section{REFERENCES}

Abubakar, S. \& A. Achmad. 2013. Tumbuhan air (panduan pengajaran).
LepKhair. Universitas Khairun. Ternate. $96 \mathrm{p}$.

Akbar, N.I., I. Marus, S. Haji, S. Abdullah, F.S. Umalekhoa, M. Ibrahim, A. Ahmad, A. Ibrahim, Kahar, \& I. Tahir. 2017. Struktur komunitas hutan mangrove di Teluk Dodinga, Kabupaten Halmahera Barat Provinsi Maluku Utara. J. Enggano, 2(1): 7889.

https://doi.org/10.31186/jenggano.2.1 .78-89

Alongi, D.M. 2002. Present the state and future of the world's mangrove forests. Environmental Conservation, 29(3): 331-349. https://doi.org/10.1017/S0376892902 000231

Alongi, D.M. 2009. The energetics of mangrove forests. Springer Science and Business Media BV. New York. $216 \mathrm{p}$.

https://www.springer.com/gp/book/97 81402042706

Barbier, E.B., H. Elementary, C. Kennedy, E.W. Koch, A.C. Stier, \& B.R. Silliman. 2011. The value of estuarine and coastal ecosystem services. Ecological Monographs, 81(2): 169193. https://doi.org/10.1890/10-1510.1

Bengen, D.G. 2002. Ekosistem dan sumberdaya alam pesisir dan laut serta prinsip pengelolaannya. sinopsis. pusat kajian sumberdaya pesisir dan lautan. Institut Pertanian Bogor. Bogor. $66 \mathrm{p}$.

Danielsen, F., M.K. Sorensen, M.F. Olwig, V. Selvam, F. Parish, N.D. Burgess, T. Hiraishi, V.M. Karunagaran, M.S. Rasmussen, L.B. Hansen, A. Quarto, $\&$ N. Suryadiputra. 2005. The Asian tsunami: a protective role for coastal vegetation. Science, 310(5748): 643. http://doi.org/10.1126/science. 111838 7

Donato, D.C., J.B. Kauffman, D. Murdiyarso, S. Kurnianto, M. 
Stidham, \& M. Kanninen. 2011. Mangroves among the most carbonrich forests in the tropics. Natur Geoscience, 4: 293-297. https://doi.org/10.1038/ngeo1123

Food and Agriculture Organization (FAO). 2007. The World's Mangroves 19802005. FAO Forestry Paper 153. Forest resources division, FAO. Rome Italy. $77 \mathrm{p}$.

http://www.fao.org/3/ap428e/ap428e0 $0 . p d f$

Giri, C., Z. Zhu, L.L. Tieszen, A. Singh, S. Gillette, \& J.A. Kelmelis. 2008. Mangrove forest distributions and dynamics (1975-2005) of the tsunami-affected region of Asia. $J$. of Biogeography, 35: 519-528. https://doi.org/10.1111/j.13652699.2007.01806.x

Giri, C., J. Long, S. Abbas, R.M. Murali, F.M. Qamer, B. Pengra, \& D. Thau. 2015. Distribution and dynamics of mangrove forests of South Asia. $J$ Environmental Management, 148: 101-111. https://doi.org/10.1016/j.jenvman.201 4.01 .020

Indrayanti, M.D., A. Fahrudin, \& I. Setiobudiandi. 2015. Penilaian jasa ekosistem mangrove di Teluk Blanakan Kabupaten Subang. J Ilmu Pertanian Indonesia, 20(2): 92-96. https://journal.ipb.ac.id/index.php/JIP I/article/view/9950

Iswahyudi., C. Kusmana, A. Hidayat, \& B.P. Noorachmat. 2019. Evaluasi kesesuaian lahan untuk rehabilitasi hutan mangrove Kota Langsa Aceh. J. matematika, sains, dan teknologi, 20(1): 45-56. https://doi.org/10.33830/jmst.v20i1.8 9.2019

Jusoff, K. 2013. Review: Malaysian mangrove forests and their significance to the coastal marine environment. Pol. J. Environ. Stud., 22(4): 979-1005. https://pdfs.semanticscholar.org/3316/ 1a8664107f69cb2a6006ebc30fea162d 6c5b.pdf

Kathiresan, K. \& N. Rajendran. 2005. Mangrove ecosystems of the Indian Ocean region. Indian J. Mar. Sci., 34(1): 104-113.

http://nopr.niscair.res.in/bitstream/12 3456789/4170/1/IJMS\%2034(1)\%201 04-113.pdf

Mahmud, M.A. 2017. Gerakan hijau di arus poros maritim (rehabilitasi mangrove Maluku Utara sebagai pilar ekonomi biru). Prosiding Seminar Nasional KSP2K II 2017, Seminar Nasional Kemaritiman dan Sumberdaya Pulaupulau Kecil II, Ternate 25-26 Oktober 2017. $112-121 \mathrm{pp}$.

Masithah, D., A. Kustanti, \& R. Hilmanto. 2016. Nilai ekonomi komoditi hutan mangrove di desa Merak Belantung Kecamatan Kalianda Kabupaten Lampung Selatan. J. Sylva Lestari, 4(1): 69-80. http://doi.org/10.23960/js11469-80

McIvor A., I. Molller, T. Spencer, \& M. Spalding. 2012. Reduction of wind and swell waves by mangroves. Natural coastal protection series: report 1. Cambridge research unit working paper 40. Natural coastal protection series. The Nature Conservancy and Wetlands International. English. 27 p.

Mughofar, A., M. Masykuri, \& P. Setyono. 2018. Zonasi dan komposisi vegetasi hutan mangrove pantai Cengkrong Desa Karanggandu Kabupaten Trenggalek Provinsi Jawa Timur. $J$ Pengelolaan Sumberdaya Alam dan Lingkungan, 8(1): 77-85. https://doi.org/10.29244/jpsl.8.1.7785

Murhum, M.A., S. Abubakar, \& S.E. Widiyanti. 2018. Sumberdaya pesisir dan laut Desa Gotowasi (Studi Ekologi, Ekonomi dan Sosial). 
Samudera Biru Press. Yogyakarta. $134 \mathrm{p}$.

Noor, R.Y., M. Khazali, \& I.N.N. Suryadiputra. 2006. Panduan pengenalan mangrove di Indonesia. PHKA/ Wetland InternationalIndonesia Programe. Bogor. 220 p.

Prihadi, D.J., I. Riyantini, \& M.R. Ismail. 2018. Pengelolaan kondisi ekosistem mangrove dan daya dukung lingkungan kawasan wisata bahari mangrove di Karangsong Indramayu. J. Kelautan Nasional, 13(1): 53-64. http://doi.org/10.15578/jkn.v1i1.6748

Polidoro, B.A., K.E. Carpenter, L. Collins, N.C. Duke, A.M. Ellison, J.C. Ellison, E.J. Farnsworth, E.S. Fernando, K. Kathiresan, N.C. Coedam, S.R. Livingstone, T. Miyagi, G.E. Moore, V.N. Nam, J.E. Ong, J.H. Primavera, S.G. III. Salmo, J.C. Sanciangco, S. Sukardjo, Y. Wang, \& J.W.H. Yong. 2010. The loss of species: risk of mangrove extinction and geographical area of global concern. PLoS One, 5(4): e10095.

http://doi.org/10.1371/journal.pone.00 10095

Rumalean, A.S., F. Purwanti, B. Hendrarto, \& S. Hutabarat. 2019. Struktur komunitas hutan mangrove pada kawasan Mempawah mangrove park di Desa Pasir Mempawah Hilir. $J$ Ilmu dan Teknologi Kelautan Tropis, 11(1): 221-230.

http://doi.org/10.29244/jitkt.v11i1.257 04

Siringoringo, Y.N., Yunasfi, \& Desrita. 2017. Struktur komunitas mangrove di hutan mangrove Kelurahan Belawan Sicanang Kecamatan Medan Belawan Provinsi Sumatera Utara. $J$. Auacoastmarine, 5(2): 1-7.

https://jurnal.usu.ac.id/index.php/aqua coastmarine/article/view/17895/7629

Tefarani, R., N. Kariada, T. Martuti, \& S. Ngabekti. 2019. Keanekaragaman spesies mangrove dan zonasi di wilayah Kelurahan Mangunharjo Kecamatan Tugu Kota Semarang. J Life Science, 8(1): 41-53. http://doi.org/10.15294/lifesci.v8i1.29 989

Thomas, N., R. Lucas, P. Bunting, A, Hardy, A, Rosenqvist, \& M. Simard. 2017. Distribution and drivers of global mangrove forest change, 1996-2010. J. Plos One, 12(6): e0179302. https://doi.org/10.1371/journal.pone.0 179302

Usman, L., Syamsuddin, \& S.N. Hamzah. 2013. Analisis vegetasi mangrove di Pulau Dudepo Kecamatan Anggrek Kabupaten Gorontalo Utara. $J$. Ilmiah Perikanan dan Kelautan, 1(1): 11-17.

http://ejurnal.ung.ac.id/index.php/nike /article/view/1211/961

Valiela, I., J.L Bowen, \& J.K York. 2001. Mangrove forests: one of the world's threatened major tropical environments. BioScience, 51(10): 807-815. https://doi.org/10.1641/00063568(2001)051[0807:MFOOTW]2.0. $\mathrm{CO} ; 2$

Vo, Q.T., C. Kuenzer, Q.M. Voc, F. Moder, \& N. Oppelt. 2012. Review of valuation methods for mangrove ecosystem services. Ecological Indicator, 23: 431-446. http://doi.org/10.1016/j.ecolind.2012. 04.022

Wahyudi, A., B. Hendrarto, \& A. Hartoko. 2014. Penilaian kerentanan habitat mangrove di Kelurahan Mangunharjo, Kecamatan Tugu, Kota Semarang terhadap variabel oseanografi berdasarkan metode cvi (coastal vulnerability index). Management of Aquatic Resources J., 3(1): 89-98. https://ejournal3.undip.ac.id/index.ph $\mathrm{p} / \mathrm{maquares} /$ article/view/4425/4264

Zamdial, 2016. Analisa struktur komunitas hutan mangrove di Desa Pasar Sebelah Kecamatan Kota Mukomuko 
Distribution and Community Structure of Mangrove in Donrotu ...

Kabupaten Mukomuko. J. Enggano, Received :03 August 2019

1(2): 29-37. Reviewed : 16 Januari 2020

https://ejournal.unib.ac.id/index.php/j Accepted :05 April 2020

urnalenggano/article/view/1061/889 